\title{
GAMBARAN KONTROL DIRI TERHADAP PERILAKU KONSUMTIF PRIA DEWASA AWAL YANG GEMAR BERBEBELANJA DI MALL KAWASAN JAKARTA
}

\author{
Yoseph Nirvana M. Lubis
}

Rilla Sovitriana

\begin{abstract}
Abstrak
Hobi belanja memang identik dengan wanita namun bukan berarti pria tidak pernah berbelanja.Khususnya pria-pria muda yang mulai menunjukkan kebiasaan berbelanja yang lebih perempuan. Mereka memandangnya lebih menyenangkan dan lebih terbuka bahwa mereka terhibur (dengan berbelanja) sehingga menimbulkan perilaku konsumtif . Perilaku Konsumtif adalah perilaku yang tidak lagi berdasarkan pada pertimbangan yang rasional, melainkan karena adanya keinginan yang sudah mencapai taraf yang sudah tidak rasional lagi. Dalam hal berbelanja yang dilakukan konsumen perlu adanya kontrol diri. Kontrol Diri merupakan kemampuan yang dimiliki oleh individu untuk selalu mengarahkan, mengendalikan, mengatur serta mengubah perilakunya ke arah yang lebih positif dari sebelumnya. Penelitian ini menggunakan metode penelitian kualitatif. Pengumpulan data menggunakan wawancara dan observasi. Responden yang digunakan dalam penelitian ini adalah tiga pria dewasa awal dengan rentang usia 20-40 tahun yang memiliki kegemaran berbelanja di mall kawasan Jakarta. Data penelitian yang didapatkan dari wawancara dan observasi dijabarkan sesuai dengan tujuan penelitian. Hasil yang didapat dari penelitian ini adalah ketiga subjek telah memiliki kontrol diri terhadap perilaku konsumtif berkisar dari kurang sampai baik. Kesimpulan untuk ketiga subjek mengenai kontrol diri dapat dilihat dari ciri-ciri dan aspek-aspek kontrol diri.Sedangan untuk perilaku konsumtif ketiga subjek dapat dilihat dari aspek-aspek perilaku konsumtif dan Indikator perilaku konsumtif.
\end{abstract}

Keywords: kontrol diri, perilaku konsumtif, pria dewasa awal

\section{PENDAHULUAN}

Hobi belanja memang identik dengan wanita namun bukan berarti pria tidak pernah berbelanja. Di dalam berita (Vivanews.com) Nielsen merilis hasil survey terbarunya mengenai tren berbelanja. Dalam survey ini, ditemukan kenaikan persentase pembelanja pria. Pada tahun 2011, wanita yang berbelanja hanya 74 persen, sedangkan sisanya 26 persen dilakukan kaum pria. Associate Director
Retailer Service di Nielsen, Feby Ramaun, dalam keterangan pers di Jakarta, mengatakan satu dari empat pembelanja utama adalah pria kondisi ini naik jika dibandingkan dengan tahun lalu yang hanya 19 persen.

Biasanya pria yang sering ditemui di mall selain sekelompok remaja adalah pria yang sudah memasuki masa dewasa awal. 
Craig Ryder (2011) mengatakan bahwa pria muda yang gemar belanja tidak lagi terpaku pada stereotip mengenai pria dan kebiasaan belanja. Individu yang tidak dapat mengontrol perilakunya dalam hal berbelanja dimana perilaku tersebut dilakukan secara berlebihan dan tidak irasional serta lebih mengutamakan keinginan daripada kebutuhan dapat diartikan sebagai tindakan konsumtif.

Menurut Lubis (dalam Sumartono, 2002) mengatakan perilaku konsumtif adalah perilaku yang tidak lagi berdasarkan pada pertimbangan yang rasional, melainkan karena adanya keinginan yang sudah mencapai taraf yang sudah tidak rasional lagi. Untuk itu agar individu dapat menanggulangi perilaku konsumtif perlu adanya kontrol diri. Menurut Calhoun dan Acocella (1990) kontrol diri (selfcontrol) sebagai pengaturan proses-proses fisik, psikologis, dan perilaku seseorang;

\section{RUMUSAN MASALAH}

Rumusan masalah dalam penelitian ini:

1. Bagaimana ciri - ciri kontrol diri pria dewasa awal terhadap perilaku konsumtifnya?

2. Apa saja aspek - aspek kontrol diri pria dewasa awal terhadap perilaku konsumtifnya?

3. Apa saja aspek - aspek perilaku konsumtif pria dewasa awal? dengan kata lain serangkaian proses yang membentuk dirinya sendiri. Goldfried dan Merbaum (dalam Lazarus, 1976), mendefinisikan kontrol diri sebagai suatu kemampuan untuk menyusun, membimbing, mengatur dan mengarahkan bentuk perilaku yang dapat membawa individu ke arah konsekuensi positif.

Berdasarkan wawancara terbatas dengan salah satu subjek dirinya mengatakan bahwa kegiatan berbelanja membuatnya merasa senang karena dapat memilih dan memiliki barang yang disukai namun di satu sisi dirinya pun lebih banyak mengeluarkan dana untuk pembelian sehingga perlu untuk mengontrol dirinya dengan hanya membawa uang cash yang seperlunya tanpa membawa kartu atm maupun kartu kredit yang dirasa cukup efektif mengatasi perilaku konsumtifnya.

4. Apa saja yang menjadi indikator perilaku konsumtif pria dewasa awal?

\section{TUJUAN PENELITIAN}

Tujuan dari penelitian ini adalah:

1. Untuk mengetahui ciri - ciri kontrol diri konsumen gemar berbelanja di mall

2. Untuk mengetahui aspek - aspek kontrol diri konsumen yang gemar berbelanja di mall 
3. Untuk mengetahui aspek - aspek perilaku konsumtif khususnya pria dewasa awal yang gemar berbelanja di mall

4. Untuk mengetahui indikator perilaku konsumtif khususnya pria dewasa awal yang gemar berbelanja di mall

\section{TINJAUAN PUSTAKA}

\section{KONTROL DIRI}

\section{DEFINISI}

Menurut Calhoun dan Acocella (1990) kontrol diri (self-control) sebagai pengaturan proses-proses fisik, psikologis, dan perilaku seseorang dengan kata lain serangkaian proses yang membentuk dirinya sendiri. Goldfried dan Merbaum (dalam Lazarus, 1976), mendefinisikan kontrol diri sebagai suatu kemampuan untuk menyusun, membimbing, mengatur dan mengarahkan bentuk perilaku yang dapat membawa individu kearah konsekuensi positif.

Berdasarkan pengertian dari para ahli tersebut diatas, maka dapat disimpulkan kontrol diri merupakan kemampuan yang dimiliki oleh individu untuk selalu mengarahkan, mengendalikan, mengatur serta mengubah perilakunya ke arah yang lebih positif dari sebelumnya. Semakin tinggi kontrol diri yang dimiliki maka semakin baik keyakinan dalam membuat suatu keputusan dan mengambil suatu tindakan untuk mencapai hasil yang diinginkan dan menghindari hasil yang tidak diinginkan. .

\section{CIRI-CIRI KONTROL DIRI}

Berikut ciri-ciri kontrol diri menurut

Goldfried (Queen, 2014 : 176), yaitu:

a. Kemampuan untuk mengontrol perilaku atau tingkah laku implusif yang ditandai dengan kemampuan menghadapi stimulus yang tidak diinginkan dengan cara mencegah menjauhi stimulus, merapatkan tenggang waktu diantara stimulus sebelum berakhir dan membatasi intensitas stimulus, kemampuan membuat perencanaan dalam hidup, mampu mengatasi frustasi dan ledakan emosi serta kemampuan untuk menentukan siapa yang mengendalikan perilaku, dalam hal ini bila individu tidak mampu mengontrol dirinya sendiri maka individu menggunakan faktor eksternal.

b. Menunda kepuasan dengan segera untuk keberhasilan mengatur perilaku dengan mencapai sesuatu yang lebih berharga atau lebih diterima dalam masyarakat.

c. Mengantisipasi peristiwa, yaitu kemampuan untuk mengantisipasi keadaan melalui berbagai pertimbangan secara relative objektif. Hal ini didukung dengan adanya informasi yang dimiliki individu.

d. Menafsirkan peristiwa, yaitu kemampuan untuk menilai dan menafsirkan suatu keadaan atau peristiwa dengan cara memperhatikan segi-segi positif secara subjektif.

e. Mengambil keputusan yaitu kemampuan untuk memilih suatu tindakan 
berdasarkan pada sesuatu yang diyakini atau disetujuinya.

Berdasarkan uraian diatas dapat disimpulkan bahwa ciri-ciri kontrol diri sangat bergantung oleh individu dalam menerapkannya dimana individu dapat mengontrol perilakunya dengan cara menghadapi stimulus yang yang tidak diinginkan dengan cara mencegah menjauhi stimulus, menunda kepuasan,mengantisipasi peristiwa secara relatif objektif, menafsirkan peristiwa dengan cara memperhatikan segisegi positif subjektif dan kemampuan mengambil keputusan pada hal yang diyakini.

\section{ASPEK-ASPEK KONTROL DIRI}

Menurut Averill dkk (dalam Sarafino, 1994 ) mengungkapkan bahwa ada lima aspek kontrol diri yang digunakan dalam kehidupan sehari- hari, yaitu :

a. Kontrol perilaku (behavioral control)

Kontrol perilaku (behavioral control) adalah kemampuan dalam mengambil tindakan nyata untuk mengurangi dampak dari stresor. Kemungkinan tindakan ini dapat mengurangi tingkat ketegangan suatu atau mempersingkat durasi masalah.

b. Kontrol kognitif (cognitive control) Kontrol kognitif (cognitive control) adalah kemampuan seseorang dalam menggunakan proses berpikir atau strategi ketika menghadapi permasalahan. Hal ini dapat dilakukan dengan cara memfokuskan pikiran terhadap hal-hal yang menyenangkan, netral, atau suatu sensasi yang berbeda dengan situasi yang dihadapinya.

c. Kontrol dalam pengambilan keputusan (decisional control)

Kontrol dalam pengambilan keputusan (decisional control ) adalah suatu kesempatan untuk memilih anatara pilihan alternative atau tindakan yang umum. Misalnya pasien yang berada dalam perawatan rumah sakit diberikan pilihan dalam memilih prosedur perawatan yang akan dijalaninya serta akibat dari pilihannya tersebut.

d. Kontrol terhadap informasi (informational control)

Kontrol terhadap informasi (informational control) meliputi halhal yang berkaitan dengan pengetahuan tentang masalah yang dihadapinya, seperti apa yang akan terjadi, mengapa, dan konsekuensi apa yang akan diterimanya.

e. Kontrol terhadap pengalaman masa lalu ( retrospective control)

Kontrol terhadap pengalaman masa lalu ( retrospective control) adalah keyakinan terhadap apa atau siapa yang menyebabkan suatu permasalahan tersebut.

Berdasarkan pembagian aspek kontrol diri menurut Sarafino (1994), maka untuk mengukur kontrol diri terdiri dari lima aspekaspek yaitu kontrol perilaku, kontrol kognitif, kontrol dalam pengambilan keputusan, kontrol 
terhadap informasi, dan kontrol terhadap pengalaman masa lalu.

\section{PERILAKU KONSUMTIF}

Perilaku konsumtif adalah perilaku yang tidak lagi berdasarkan pada pertimbangan yang rasional, melainkan karena adanya keinginan yang sudah mencapai taraf yang sudah tidak rasional lagi menurut Lubis (Sumartono, 2002). Sedangkan Yayasan Lembaga Konsumen Indonesia (dalam Sumartono, 2002) mengatakan perilaku konsumtif adalah kencenderungan manusia untuk menggunakan konsumsi tanpa batas dan manusia lebih mementingkan faktor keinginan dari pada kebutuhan. Sedangkan Anggasari (dalam Sumartono, 2002) mengatakan perilaku konsumtif adalah tindakan membeli barangbarang yang kurang atau tidak diperhitungkan sehingga sifatnya menjadi berlebihan.

Berdasarkan definisi dari para tokoh diatas, maka peneliti menyimpulkan bahwa perilaku konsumtif adalah perilaku seseorang yang melakukan konsumsi tiada batas dan diluar rasional yang ia miliki . Dimana manusia lebih mementingkan keinginan daripada kebutuhan sehingga lebih besar keinginan dari pada kebutuhan.

\section{ASPEK-ASPEK PERILAKU KONSUMTIF}

Aspek-aspek perilaku konsumtif menurut Lina dan Rasyid (dalam Priaz dan Umi , 2013) yaitu: a. Aspek Pembelian Impulsif, yaitu Aspek pembelian yang didasarkan pada dorongan dalam diri individu yang muncul tiba-tiba.

b. Aspek Pembelian Tidak Rasional, yaitu Aspek pembelian yang dilakukan bukan karena kebutuhan, tetapi karena gengsi agar dapat dikesankan sebagai orang yang modern atau mengikuti mode.

c. Aspek Pembelian Yang Berlebihan yaitu Aspek pembelian suatu produk secara berlebihan yang dilakukan oleh konsumen.

Berdasarkan uraian di atas, maka dapat disimpulkan bahwa perilaku konsumtif terdiri dari 3 aspek - aspek, yaitu Aspek pembelian impulsif, aspek pembelian tidak rasional, dan aspek pembelian yang berlebihan.

\section{INDIKATOR PERILAKU KONSUMTIF}

Indikator perilaku konsumtif menurut Sumartono (2002), yaitu :

a. Membeli produk karena penawaran khusus

b. Membeli produk karena penampilannya

c. Membeli produk demi menjaga penampilan diri dan gengsi

d. Membeli produk atas pertimbangan harga (bukan atas dasar manfaat atau kegunaannya )

e. Membeli produk hanya sekedar menjaga simbol status

f. Memakai produk karena unsur konformitas terhadap model yang mengiklankan

g. Membeli produk dengan harga mahal untuk meningkatkan rasa percaya diri

h. Mencoba lebih dari dua produk sejenis 
Berdasarkan uaraian diatas maka diketahui indikator-indikator perilaku konsumtif, yaitu membeli produk karena penawaran khusus, membeli produk karena penampilannya menarik, membeli produk demi menjaga penampilan diri dan gengsi, membeli produk atas pertimbangan harga (bukan atas dasar manfaat atau kegunaannya), membeli produk hanya sekedar menjaga simbol status, memakai produk karena unsur konformitas terhadap model yang mengiklankan, membeli produk dengan harga mahal untuk meningkatkan rasa percaya diri, dan mencoba lebih dari dua produk sejenis.

\section{DEWASA AWAL}

\section{DEFINISI}

Menurut Hurlock (1999) mengatakan bahwa masa dewasa awal dimulai pada umur 18 tahun sampai umur 40 tahun, saat perubahan- perubahan fisik dan psikologis yang menyertai berkurangnya kemampuan reproduktif. Santrock (2002) mengatakan masa dewasa awal adalah masa untuk bekerja dan menjalin hubungan dengan lawan jenis, terkadang menyisakan sedikit waktu untuk hal lainnya. Kenniston (dalam Santrock, 2002) mengemukakan masa muda (youth) adalah periode kesementaraan ekonomi dan pribadi, dan perjuangan antara ketertarikan pada kemandirian dan menjadi terlibat secara sosial. Periode masa muda rata-rata terjadi 2 sampai 8 tahun, tetapi dapat juga lebih lama

Berdasarkan definisi dari para ahli, maka penulis menyimpulkan definisi dewasa awal adalah individu yang berada pada rentang usia antara 20 hingga 40 tahun dimana terjadi perubahan fisik dan psikologis pada diri individu yang disertai berkurangnya kemampuan reproduktif, merupakan masa dimana individu tidak lagi harus bergantung secara ekonomis, sosiologis, maupun psikologis pada orangtuanya, serta masa untuk bekerja, terlibat dalam hubungan masyarakat, dan menjalin hubungan dengan lawan jenis.

\section{METODE PENELITIAN}

Metode yang digunakan dalam penelitian ini adalah metode penelitian kualitatif dengan pendekatan studi kasus. Metode pengumpulan data dalam penelitian ini menggunakan wawancara dan observasi. Alat bantu pengumpulan data yang digunakan adalah pedoman wawancara, pedoman observasi, catatan lapangan, alat perekam, dan foto.

\section{SUBJEK PENELITIAN}

Dalam penelitian ini, pencarian dan penetapan responden dilakukan berdasarkan beberapa karakteristik sehingga sesuai dengan permasalahan dan tujuan penelitian. Subjek berjumlah tiga orang dengan rentang usia sekitar 20-40 tahun yang merupakan seorang pria dewasa awal yang memiliki kegemaran berbelanja di mall kawasan Jakarta, dengan karakteristik:

a. Bersedia untuk diteliti

b. Berdomisili di Jakarta

Data dari observasi dan wawancara dipilih, dikategorikan berdasarkan teori dan 
pedoman. Teknik analisa yang digunakan dan teori dalam desain penelitian.

adalah pattern matching menggunakan konsep

\section{ANALISIS DATA DAN PEMBAHASAN}

\section{Tabel 1}

Ciri-ciri kontrol diri dan Aspek-aspek kontrol diri

\section{No Komponen Teoritik Sub I Sub II Sub III}

1.Ciri - ciri Kontrol Diri

Goldfried ( Queen , 2014 : 176)

a.Kemampuan untuk

mengontrol perilaku

atau tingkah laku impulsif

yang ditandai dengan kemampuan

menghadapi stimulusyang tidak diinginkan

$\begin{array}{llll}\text { b.Menunda kepuasan dengan } & \sqrt{ } & \sqrt{ } & -\end{array}$

segera untuk keberhasilan

mengatur perilaku dengan

Tabel 2

Aspek-aspek perilaku konsumtif dan Indikator perilaku

konsumtif

No Komponen Teoritik

Sub I Sub II Sub III

3. Aspek - Aspek Perilaku

Konsumtif ( Sumartono ,2002)

mencapai sesuatu yang lebih

berharga atau lebih diterima

dalam masyarakat

c.Mengantisipasi peristiwa

d.Menafsirkan peristiwa

e.Mengambil keputusan

2. Aspek - Aspek Kontrol Diri

Averill (Sarafino , 1994)

a.Kontrol Perilaku

b.Kontrol Kognitif

c.Kontrol dalam pengambilan

keputusan

d.Kontrol terhadap informasi

e.Kontrol terhadap pengalaman

masalalu

a.Pembelian Impulsif

b.Pembelian Tidak Rasional

c.Pembelian Yang Berlebihan

4. Indikator Perilaku Konsumtif

(Hurlock,1993:259) 


\author{
a.Membeli produk karena penawaran \\ khusus \\ b.Membeli produk karena \\ penampilannya menarik \\ c.Membeli produk demi menjaga \\ $\sqrt{ }$ \\ penampilan diri dan gengsi \\ d.Membeli produk atas pertimbangan \\ harga (bukan atas dasar \\ manfaat atau kegunaannya )
}

Ciri - ciri kontrol diri untuk subjek pertama yaitu kemampuan untuk mengontrol perilaku impulsif yang ditandai dengan kemampuan menghadapi stimulus yang tidak diinginkan, menunda kepuasan, menafsirkan peristiwa, dan mengambil keputusan. Untuk subjek kedua memiliki ciri - ciri kontrol diri yaitu kemampuan untuk mengontrol perilaku impulsif yang ditandai dengan kemampuan menghadapi stimulus yang tidak diinginkan, menunda kepuasan, mengantisipasi peristiwa menafsirkan peristiwa, dan mengambil keputusan sedangkan untuk subjek ketiga hanya dimiliki ciri- ciri kontrol diri dalam hal menafsirkan peristiwa. Aspek - aspek kontrol diri subjek pertama dan kedua memiliki kesamaan yaitu kontrol perilaku, kontrol kognitif, kontrol dalam pengambilan keputusan dan kontrol terhadap informasi namun untuk subjek ketiga hanya dimiliki kontrol terhadap informasi. Sedangkan untuk aspek- aspek
e.Membeli produk hanya sekedar

menjaga simbol status

d.Memakai produk karena unsur

konformitas terhadap model yang

mengiklankan

e.Membeli produk dengan harga mahal $\sqrt{ }$

untuk meningkatkan rasa percaya diri

f.Mencoba lebih dari dua produk sejenis $\sqrt{ } \quad \sqrt{ } \quad \sqrt{ }$

perilaku konsumtif ketiga subjek sama- sama memiliki aspek pembelian impulsif, aspek pembelian tidak rasional, dan aspek pembelian yang berlebihan. Selanjutnya mengenai indikator perilaku konsumtif untuk subjek pertama membeli produk demi menjaga diri dan gengsi, membeli produk hanya sekedar menjaga simbol status, memakai produk karena unsur konformitas terhadap model yang mengiklankan, membeli produk dengan harga mahal untuk meningkatkan rasa percaya diri, mencoba lebih dari dua produk sejenis. Untuk subjek kedua membeli produk karena tampilannya menarik dan mencoba lebih dari dua produk sejenis. Sedangkan indikator subjek ketiga yaitu membeli produk karena penawaran khusus, membeli produk demi menjaga penampilan diri dan gengsi, membeli produk hanya sekedar menjaga simbol status, memkai produk karena unsur konformitas terhadap model yang mengiklankan, membeli 
produk dengan harga mahal untuk meningkatkan rasa percaya diri, dan mencoba

\section{KESIMPULAN}

Dari hasil penelitian dapat diambil kesimpulan, yaitu sebagai berikut:

Ciri-ciri kontrol diri yang dimiliki subjek pertama yaitu kemampuan mengontrol perilaku impulsif yang ditandai dengan kemampuan menghadapi stimulus yang tidak diinginkan, menunda kepuasan, menafsirkan peristiwa dan mengambil keputusan namun belum memiliki kemampuan dalam mengantisipasi peristiwa. Untuk subjek kedua, yaitu kemampuan mengontrol perilaku impulsif yang ditandai dengan kemampuan menghadapi stimulus yang tidak diinginkan, menunda kepuasan, mengantisipasi peristiwa, menafsirkan peristiwa dan mengambil keputusan. Subjek ketiga, yaitu hanya memiliki kemampuan menafsirkan peristiwa.

Mengenai aspek - aspek kontrol diri yang peneliti dapatkan, subjek pertama memiliki aspek - aspek kontrol diri, yaitu kontrol perilaku, kontrol kognitif, kontrol dalam pengambilan keputusan dan kontrol terhadap informasi namun untuk kontrol terhadap pengalaman masa lalu subjek tidak memilikinya sebab perilaku konsumtifnya tidak terkait dengan masa lalu. Untuk subjek kedua memiliki kontrol perilaku, kontrol kognitif, kontrol dalam pengambilan keputusan dan kontrol terhadap informasi namun belum lebih dari dua produk sejenis.

memiliki kontrol terhadap pengalaman masa lalu. Sedangkan untuk subjek ketiga hanya memiliki kontrol terhadap informasi namun belum memiliki kontrol perilaku, kontrol kognitif, kontrol dalam pengambilan keputusan dan kontrol terhadap pengalaman masa lalu.

$$
\text { Selain ciri - ciri dan aspek - aspek }
$$
kontrol diri, peneliti juga dapat mengetahui aspek - aspek perilaku konsumtif. Berdasarkan hasil penelitian yang peneliti dapatkan aspek aspek perilaku konsumtif ketiga subjek tersebut adalah aspek pembelian impulsif, aspek pembelian tidak rasional dan aspek pembelian yang berlebihan.

Indikator perilaku konsumtif subjek pertama, yaitu membeli produk demi menjaga diri dan gengsi, membeli produk hanya sekedar menjaga simbol status, memakai produk karena unsur konformitas terhadap model yang mengiklankan, membeli produk dengan harga mahal untuk meningkatkan rasa percaya diri, dan mencoba lebih daru dua produk sejenis. Untuk subjek kedua yaitu membeli produk karena penampilannya menarik, membeli produk demi menjaga penampilan diri dan gengsi dan mencoba lebih daru dua produk sejenis. Dan untuk subjek ketiga yaitu membeli produk karena penawaran khusus, membeli produk demi menjaga diri dan gengsi, membeli produk hanya sekedar menjada simbol status, memakai produk karena unsur konformitas 
terhadap model yang mengiklankan, membeli produk dengan harga mahal untuk meningkatkan rasa percaya diri, dan mencoba lebih daru dua produk sejenis

\section{Daftar Pustaka}

Ayu Khairunnisa. (2013). Hubungan Religiusitas dan Kontrol Diri dengan Perilaku Seksual Pranikah Remaja di Man 1 Samarinda. Ejournal Psikologi. Vol. 1, No 2, h. 220-229

Calhoun, J.F. Acocella, J.R. (1990). Psychology of Adjusment and Human Relationship. New York : McGraw Hill, Inc

Chaplin, J.P. (2005). Kamus Lengkap Psikologi. Jakarta: PT. Rajagrafindo Persada

Dina Andi Fasilita. (2012). Kontrol Diri Terhadap Perilaku Agresif Ditinjau Dari Usia Satpol PP Kota Semarang. Journal Psychology of Social and Industry. Vol. 1, No.2, h. 34-40

Engel, J. Blackwell, R D. Miniard, P W. (1994). Perilaku Konsumen edisi ke6. Jakarta : Binarupa Aksara

Fadilah Aulia Rahma dan Muhammad Reza. (2013). Hubungan Antara Pemebentukan Identitas Diri dengan Perilaku Konsumtif Pembelian Merchandise Pada Remaja. Vol.1, No.3, h.1-6

Hurlock, Elizabeth B. (1999). Piskologi Perkembangan Suatu Pendekatan Sepanjang Rentang Kehidupan. Edisi Kelima. Jakarta : Erlangga

Lazarus, R.S. 1976. Paterns of Adjusment. Tokyo : McGraw Hill, Inc

Mangkunegara, A. P. (2002). Perilaku Konsumen. Edisi Revisi. Bandung : PT. Refika Aditama.
Melati, Rostiana, dan Aswini Widjaja. (2007).

Pengaruh Kontrol Diri terhadap Pembelian Impulsif pada Remaja Awal. Jurnal Psikologi Industri dan Organisasi. Vol.9, No. 2, h. 115-113

Moleong, Lexy J. (2011). Metodologi Penelitian Kualitatif. Edisi Revisi. Bandung: PT Remaja Rosdakarya.

Nur Fitriani, Prasetyo Budi Widodo, Nailul Fauziah. ( 2013) Hubungan Anatara Konformitas Dengan Perilaku Konsumtif Pada Mahasiswa di Genuk Indah Semarang. Jurnal Psikologi UNDIP. Vol.2, No.1. hal 55-68

Poerwandari, Kristi. (2013). Pendekatan Kualitatif untuk Penelitian Perilaku Manusia. Depok: LPSP3 UI

Priaz Rizka Fardhani dan Umi Anugerah Izzati. (2013). Hubungan Antara Konformitas dan Perilaku Konsumtif Pada Remaja ( Studi Pada Siswa Kelas XI SMA TRIMUTRI Surabaya). Jurnal Psikologi UNESA. Vol.1, No.2, hal. 1-7

Queen Jales Puspahayati.(2014). Self Control Yang Mengikuti Karate dan Yang Tidak Mengikuti Karate. Jurnal Online Psikologi. Vol.2, No.1, hal.170-181

Riyan Adiputra dan Clara Moningka. ( 2012). Gambaran Perilaku Konsumtif Terhadap Sepatu Pada Perempuan Dewasa Awal. Jurnal Psikologi. Vol.5, No.2. h. 76-89

Sarafino, E. P. (1994). Health Psychology : Biopsychosocial interaction. New York : John Wiley 7 Sons

Santrock, J. W. (2003). Adolescene. Perkembangan Remaja . Edisi Keenam. Jakarta : Erlangga

Sumartono. (2002). Terperangkap dalam iklan. Bandung : CV Alfabeta

Slamet, Suprapti. (2008). Pengantar Psikologi Klinis. Jakarta: Penerbit Universitas Indonesia 
